\title{
Short Note on Biotechnological Application of Halophilic Enzymes
}

\section{Javid $\mathrm{H}^{*}$ and Zarei A}

Department of Human Genetics, Iranian Academic Center for Education, Culture \& Research (ACECR) -Fars Branch, Iran

*Corresponding author: Hossein Javid, Department of Human Genetics, Iranian Academic Center for Education, Culture \& Research (ACECR) -Fars Branch, Iran, Tel: +98-71-32335010;

\section{Review Article}

Volume 6 Issue 3

Received Date: July 05, 2021

Published Date: July 26, 2021

DOI: 10.23880 /oajmb- 16000200

Email: h.javid@acecr.ac.ir

\section{Abstract}

Evolution of life in extreme environments entails wide adaptations. Amongst these environments, those with high salt concentration are abodes to so-called halophilic microorganisms. The unique key properties of halophilic proteins not only enable them to survive in hostile and precluding environments, but also make their enzymes as precious biocatalysts in pharmaceutical, fine chemical processes, industries, food processing, detergents, waste treatments, etc., where harsh conditions prevent favorable reactions by normal enzymes. Unfortunately, due to lack of deep knowledge and proper equipment, up to know only a limited number of extremozymes have characterized and applied in appropriate industries. Discovery of new extremophiles or genetically engineering of mesophilic enzymes will open new horizons to novel applications of these invaluable enzymes in biotechnology and biotransformation.

Keywords: Halophilic Proteins; Extremozymes; Biotechnological Applications

\section{Introduction}

Environments with high salt concentration are among most extreme and strongly discordant habitats to support life. The interests in studying halophilic proteins and enzymes have risen in many laboratories, in order to understand their enigmatic strategies, by which they are capable to thrive, tolerate and colonized in such extreme habitats. It has well documented that proteins from a large variety of microorganisms are useful as biocatalysts for various industrial purposes. Among these proteins, extremozymes are in the center of attention. The main character of these extremozymes and proteins is their stability and function under very precluding conditions where other proteins cannot withstand. Due to these outstanding properties, extremozymes have considered as excellent biocatalysts in some biotechnological and industrial processes, which demand harsh conditions, e.g., high or low temperature, extreme $\mathrm{pH}$ and high ionic [1]. Table 1 summarized some halophilic proteins and related producing microorganisms.

Alpha amylases are biotechnologically important extra cellular enzymes that can perform hydrolysis of starch to products with differentlengths e.g., glucose and dextrin. These enzymes are active in a wide range of salt concentrations and $\mathrm{pH}$ (7-10) and maintain their activity at temperatures higher than $50^{\circ} \mathrm{C}$. These characteristics make these enzymes very precious for application in biotechnological processes such as starch hydrolysis, food bioprocessing, baking and textile industries and detergents [16]. Neoagaro-oligosaccharides as products of agar hydrolysis have applications as additives in pharmaceutical industries e.g., probiotics, food ingredients and cosmetics [17]. One way to produce neoagarooligosaccharides is acid hydrolysis of agar, but a drawback of this method is uncontrollable reaction, so the production of heterogeneous unwanted products, which are unfavorable for industrial scale production. 


\begin{tabular}{|c|c|c|c|}
\hline Extremozymes & Microorganisms and reference & Salt stability & Possible applications \\
\hline$\alpha$-Amylase & Halobacterium salinarium [2] & \multirow{3}{*}{ 3-4 M } & \multirow{6}{*}{$\begin{array}{c}\text { Hydrolysis of starch, food bioprocessing, } \\
\text { confectionery, baking, textile industries and } \\
\text { detergents. }\end{array}$} \\
\hline$\alpha$-Amylase & Halothermothrix orenii [3] & & \\
\hline$\alpha$-Amylase & Haloferax mediterranei [4] & & \\
\hline Amylase & Halobacillus sp. strain [5] & \multirow{3}{*}{$1-2 \mathrm{M}$} & \\
\hline Amylase & Psychromonas antracticus [6] & & \\
\hline$\alpha$-Amylase & Bacillus dipsosauri [7] & & \\
\hline Xylanase 1,2 & Halophilic bacterium, CL8 [8] & $3-4 \mathrm{M}$ & \multirow{2}{*}{$\begin{array}{l}\text { Pulp and paper production, Biobleaching } \\
\text { and detergents. }\end{array}$} \\
\hline $\begin{array}{l}\beta \text {-Xylanase, } \\
\beta \text {-Xylosidase }\end{array}$ & Halorhabdus utahensis [9] & $2-3 \mathrm{M}$ & \\
\hline$\beta$-Agarase & Pseudomonas sp. strain W7 [10] & & \multirow{2}{*}{$\begin{array}{l}\text { Production of neoagaro-oligosaccharides } \\
\text { used as probiotics, foods and cosmetics. }\end{array}$} \\
\hline Agarase & Alteromonas sp. [11] & $2-3 \mathrm{M}$ & \\
\hline Haloprotease CP1 & Pseudomonas sp. [12] & $0-4 \mathrm{M}$ & \multirow{2}{*}{$\begin{array}{l}\text { Peptides and amino acid production, } \\
\text { detergents and food processing. }\end{array}$} \\
\hline Serine protease & Halobacterium halobium $[11,13]$ & 3-4 M & \\
\hline Lipase & Halococcus dombrowskii [14] & $4 \mathrm{M}$ & $\begin{array}{l}\text { Waste treatment, pharmaceuticals, } \\
\text { detergents and food taste and aroma } \\
\text { improvement. }\end{array}$ \\
\hline$\beta$-Galactosidase & Haloferax alicantei [15] & $3-4 \mathrm{M}$ & $\begin{array}{l}\text { Production of low lactose dairy foods and } \\
\text { oligosaccharides. }\end{array}$ \\
\hline
\end{tabular}

Table 1: Summarization of halophilic enzymes, their microbial sources and applications.

Alteromonas sp., a halotolerant bacterium has found to produce agarase enzyme, which can produce neoagarooligosaccharides e.g., neoagarohexaose, neoagarobiose and neoagarotetraose [11]. $\beta$-Agarase is another halophilic enzyme that hydrolyzes agar and agarose into neoagarotetraose. A marine bacterium, Zobellia galactanivorans possesses two $\beta$-agarase genes (agaA and $\mathrm{agaB})$ and the products of both genes are able to cleave the $\beta 1 \rightarrow 4$ linkages of agarose [18]. $\beta$-Galactosidase as a member of glycosyl hydrolase family, known to be able to break glycosic bonds. Halophilic $\beta$-galactosidase has been isolated from haloarchaeon Haloferax alicantei. This halophilic enzyme retains its activity and stability in high salt concentrations and has optimal activity in $4 \mathrm{M} \mathrm{NaCl}$ [19]. The main biotechnological applications of $\beta$-Galactosidase enzyme are production of low lactose dairies e.g., low lactose milk and cheese for lactose-intolerant individuals, industrial scale production of oligosaccharides for further use in pharmaceuticals and bioprocessing of salty whey for galactooligosaccharide production probiotic applications to prevent allergic and gastrointestinal diseases by reducing adherence of enteropathogenic [20].

Xylanase is responsible to degrade xylan, but despite the importance of these enzymes, up to now, only a few xylanase with favorable properties have purified. These enzymes are derived mainly from marine habitats and halotolerant bacteria e.g., Glaciecola mesophila, Chromohalobacter sp. and
Nesterenkonia halobia. Some of these enzymes show good activity at temperatures higher than $60^{\circ} \mathrm{C}$ and with strict requirement for $\mathrm{NaCl}$. In addition, they are stable in wide $\mathrm{pH}$ ranges, 6-11 [6]. The most important applications of xylanase are in the pulp and paper production, where high $\mathrm{pH}$ and temperature is necessary for high efficient biobleaching; however, in most of these applications, xylanase should be haloalkaliphile and thermostable. Alkaliphilic xylanase used in detergents, which work in high temperature and alkaline conditions. Some less well documented applications of xylanase is in coffee extraction, production of soluble coffee, protoplasting of plant cells, production of active polysaccharides as antimicrobial agents and antioxidants and production of alkyl glycosidase for use as surfactant. Xylanase is useful in conjugation with other enzymes e.g., proteases, oxidases and isomerases [21].

Many halophilic bacteria produce lipase enzymes, e.g, Marinobacter flavomaris with $\mathrm{C}_{14}$ lipase activity can thrive optimally at 2-6\% $\mathrm{NaCl}$, Marinobacter lipolyticum thrives at $7.5 \% \mathrm{NaCl}$, Psychrofexus tropicus shows $\mathrm{C}_{4} / \mathrm{C}_{6}$ esterase activity and Sinococcus qinghaiensis grows in range of 1-25\% $\mathrm{NaCl}$. Among haloarchaeons, Halococcus dombrowski, with $\mathrm{C}_{8}$ esterase activity and Halobacterium sp. with optimal growth at 2-4 $\mathrm{M} \mathrm{NaCl}$ and maximum lipase production at $4 \mathrm{M} \mathrm{NaCl}$ and $45^{\circ} \mathrm{C}$ are recognized as the two best lipase producers [14]. Biotechnological and industrial applications of lipases include hydrolysis of fats in wastes, production of chiral 


\section{Open Access Journal of Microbiology \& Biotechnology}

intermediates of important pharmaceuticals and detergents. These applications normally required harsh conditions, e.g., high salt contents of factories waste output and use in organic media with low water activity. Biocatalysis with lipases mostly demands organic solvents to carry out reactions at low water activity [22]. Therefore, due to low water activity requirement of halophilic lipases, they are highly stable in a mixture of water-organic solvents. It has been shown that low molecular weight volatile fatty acids (VFA) are associated to taste and aroma of foods. Halophilic lipases also are used to improve the taste and the aroma of foods such as salted cheeses and butters, sausages, beverages, bakery products and salted fish sauces [23].

Proteases are enzymes with the ability to hydrolyze peptide bonds to produce simple and shorter peptides and amino acids. These enzymes are one of the largest groups of hydrolytic enzymes used in industries (approx. 60\% of world enzyme sale) with wide applications, e.g., food processing, pharmaceuticals, laundry and dish washing, diagnostic reagents and waste treatments [24]. Many halophilic proteases are detected in a wide variety of halophilic archaea; enable them to in-situ degradation of proteins. These archaea include Natronomonas pharaonis, Haloferax mediterranei, Natronococcus occultus and Natrienema sp. J7 [25]. Halobacterium halobium has shown to be an excellent protease producer with the requirement of $4 \mathrm{M} \mathrm{NaCl}$ for optimal activity and stability. This enzyme has used successfully for peptide synthesis especially for glycine-containing oligopeptides in the aqueous / organic media [11]. Detergent compatible proteases have a unique characteristic to be stable and active in high temperature $\left(50-70^{\circ} \mathrm{C}\right)$ and alkaline conditions $(\mathrm{pH} 8-12)$ in laundry [26]. Using of halophilic and halotolerant microorganisms with the ability to produce protease enzymes are more favorable in food processing under highly saline conditions e.g., processing of protein rich foods, e.g., fish, meat and soy based products [6].

One of the interesting properties of haloarchaea is their ability to harvest light energy through a photo-reactive protein, bacteriorhodopsin [27]. Since the discovery of this protein's function in 1970s, many patents for its application have issued including ATP and electricity production from sunlight, development of bioelectronics elements of computer memories and data processing units, ultra-fast light and motion detectors. Applications in nanotechnology, e.g., molecular sensors, motors and transistors also have being developed [28]. Recently this protein is used to develop military devices e.g., spatial light modulators and hybrid biomolecular. For instance, spatial light modulators have used as non-destructive system to scrutinize artillery and tank ammunition; possibly, a thin film of bacteriorhodopsin has used to obtain high resolution in real-time measurements.
Hybrid biomolecular opens new horizons for developing of telecommunication, radar-signal processing, conventional transistors, semiconductor lattices, broad-band and fiberoptic converters, and multiplexers [29].

\section{Conclusion}

Very diverse hypersaline environments exist on our planet and so are the living forms inhabited them. These organisms manifest different protein adaptations acquired during million years of evolution to remain both active and stable in such precluding habitats. It is very interesting to know that, in theory, it is possible to convert a non-halophilic protein into a halophilic one, but it requires detailed biophysical and biochemical studies as well as a deeper understanding in folding, stability, solubility and translocation of halophilic proteins which has not been really addresses in literatures. In this regard, however, many basic questions have been answered and much more yet to be learnt. Therefore, expanded understanding and optimization of aforementioned parameters can lead us to more effective, economically potential and novel enzymatic processes, which once were restricted or have not used until now. This will help to gain new and valuable knowledge on extremozymes and will open new biotechnological applications. Finally, scientists strongly believe that discovery of new extremozymes or manipulating of currently available extremophiles will offer new opportunities for developing biocatalysis and biotransformation systems [30].

\section{References}

1. Ma Y, Galinski EA, Grant WD, Oren A, Ventosa A (2010) Halophiles 2010: life in saline environments. Appl Environ Microbiol 76(21): 6971-6981.

2. Shanmughapriya S, Kiran GS, Selvin J, Gandhimathi R, Baskar TB, et al. (2009) Optimization, production, and partial characterization of an alkalophilic amylase produced by sponge associated marine bacterium Halobacterium salinarum MMD047. Biotechnology and Bioprocess Engineering 14(1): 67-75.

3. Tien Chye T, Mijts BN, Swaminathan K, Patel BKC, Divne C (2008) Crystal structure of the polyextremophilic $\alpha$-amylase AmyB from Halothermothrix orenii: details of a productive enzyme-substrate complex and an $\mathrm{N}$ domain with a role in binding raw starch. J Mol Biol 378(4): 852-870.

4. Dué EA, Kouadio JPEN, Kouakou HT, Dabonne S, Niamke SL, et al. (2008) Purification and physicochemical properties of-amylase from cockroach, Periplaneta americana (LINNAEUS), for starches saccharification. African journal of Biotechnology 7(15): 2707-2716. 


\section{Open Access Journal of Microbiology \& Biotechnology}

5. Amoozegar MA, Malekzadeh F, Malik KA (2003) Production of amylase by newly isolated moderate halophile, Halobacillus sp. strain MA-2. J Microbiol Methods 52(3): 353-359.

6. Setati ME (2010) Diversity and industrial potential of hydrolase producing halophilic/halotolerant eubacteria. African Journal of Biotechnology 9(11): 1555-1560.

7. Deutch CE (2002) Characterization of a salt-tolerant extracellular a-amylase from Bacillus dipsosauri. Lett Appl Microbiol 35(1): 78-84.

8. Wejse PL, Ingvorsen K, Mortensen KK (2003) Purification and characterisation of two extremely halotolerant xylanases from a novel halophilic bacterium. Extremophiles 7(5): 423-431.

9. Wainø M, Ingvorsen K (2003) Production of $\beta$-xylanase and $\beta$-xylosidase by the extremely halophilic archaeon Halorhabdus utahensis. Extremophiles 7(2): 87-93.

10. Sang Bong L, Je Hyeon $\mathrm{P}$, Soo Cheol Y, Jin Man K, In Soo K (2000) Sequence analysis of a $\beta$-agarase gene (pjaA) from Pseudomonas sp. isolated from marine environment. Journal of bioscience and bioengineering 89(5): 485-488.

11. Margesin R, Schinner F (2001) Potential of halotolerant and halophilic microorganisms for biotechnology. Extremophiles 5(2): 73-83.

12. Sanchez Porro C, Mellado E, Pugsley AP, Francetic O, Ventosa A (2020) The haloprotease CPI produced by the moderately halophilic bacterium Pseudoalteromonas ruthenica is secreted by the type II secretion pathway. Applied and Environmental Microbiology 75(12): 41974201.

13. Won AJ, Chan Wha K (2005) Proteomics of halophilic archaea. J Chromatogr B Analyt Technol Biomed Life Sci 815(1-2): 237-250.

14. Salameh MA, Wiegel J (2007) Purification and characterization of two highly thermophilic alkaline lipases from Thermosyntropha lipolytica. Applied and Environmental Microbiology 73(23): 7725-7731.

15. Ortega G, Lain A, Tadeo X, López Méndez B, Castaño D, et al. (2011) Halophilic enzyme activation induced by salts. Scientific reports 1(1): 1-6.

16. Shafiei M, Abed Ali Z, Amoozegar MA (2010) Purification and biochemical characterization of a novel SDS and surfactant stable, raw starch digesting, and halophilic $\alpha$-amylase from a moderately halophilic bacterium, Nesterenkonia sp. strain F. Process Biochemistry 45(5):
694-699.

17. Li J, Han F, Lu X, Fu X, Ma C, et al. (2007) A simple method of preparing diverse neoagaro-oligosaccharides with $\beta$-agarase. Carbohydrate research 342(8): 1030-1033.

18. Jam M, Flament D, Allouch J, Potin P, Thion L, et al. (2005) The endo- $\beta$-agarases AgaA and AgaB from the marine bacterium Zobellia galactanivorans: two paralogue enzymes with different molecular organizations and catalytic behaviours. Biochem J 385(3): 703-713.

19. Alqueres SMC, Almeida RV, Clementino MM, Vieira RP, Almeida WI, et al. (2007) Exploring the biotechnologial applications in the archaeal domain. Brazilian Journal of Microbiology 38(3): 398-405.

20. Kukkonen K, Savilahti E, Haahtela T, Juntunen Backman K, Korpela R, et al. (2007) Probiotics and prebiotic galactooligosaccharides in the prevention of allergic diseases: a randomized, double-blind, placebo-controlled trial. J Allergy Clin Immunol 119(1): 192-198.

21. Collins T, Gerday C, Feller G (2005) Xylanases, xylanase families and extremophilic xylanases. FEMS Microbiol Rev 29(1): 3-23.

22. Boutaiba $\mathrm{S}$, Bhatnagara $\mathrm{T}$, Haceneb $\mathrm{H}$, Mitchell $\mathrm{DA}$, Baratti JC (2006) Preliminary characterisation of a lipolytic activity from an extremely halophilic archaeon, Natronococcus sp. Journal of Molecular Catalysis B: Enzymatic 41(1-2): 21-26.

23. Kanlayakrit W, Boonpan A (2007) Screening of halophilic lipase-producing bacteria and characterization of enzyme for fish sauce quality improvement. Agriculture and Natural Resources 41(3): 576-585.

24. Amoozegar MA, Fatemi AZ, Karbalaei Heidari HR, Razavi MR (2007) Production of an extracellular alkaline metalloprotease from a newly isolated, moderately halophile, Salinivibrio sp. strain AF-2004. Microbiol Res 162(4): 369-377.

25. Shi W, Xiao Feng T, Huang Y, Gan F, Tang B, et al. (2006) An extracellular halophilic protease SptA from a halophilic archaeon Natrinema sp. J7: gene cloning, expression and characterization. Extremophiles 10(6): 599-606.

26. Vidyasagar M, Prakash S, Mahajan V, Shouche YS, Sreeramulu K, et al. (2009) Purification and characterization of an extreme halothermophilic protease from a halophilic bacterium Chromohalobacter sp. TVSP101. Braz J Microbiol 40(1): 12-19.

27. Sharma MK, Gilchrist ML (2007) Templated assembly of biomembranes on silica microspheres using 


\section{Open Access Journal of Microbiology \& Biotechnology}

bacteriorhodopsin conjugates as structural anchors. Langmuir 23(13): 7101-7112.

28. Oren A (2010) Industrial and environmental applications of halophilic microorganisms. Environ Technol 31(8-9): 825-834.

29. (2001) National Research Council (US) Committee on Opportunities in Biotechnology for Future Army
Applications, Opportunities in biotechnology for future army applications. Washington (DC), National Academies Press, US.

30. Gomes J, Steiner W (2004) The biocatalytic potential of extremophiles and extremozymes. Institute of Biotechnology and Bioprocess Engineering 42(4): 223225.

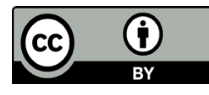

